\title{
Prevalence of Salmonellae, Listeria monocytogenes, and Fecal Coliforms in Bulk Tank Milk on US Dairies*
}

\author{
J. S. Van Kessel, ${ }^{1}$ J. S. Karns, ${ }^{1}$ L. Gorski, ${ }^{2}$ \\ B. J. McCluskey, ${ }^{3}$ and M. L. Perdue ${ }^{1}$ \\ ${ }^{1}$ USDA-ARS, Beltsville, MD 20705 \\ 2USDA-ARS, Albany, CA 94710 \\ ${ }^{3}$ USDA-APHIS-VS-CEAH, Fort Collins, CO 80526
}

\section{ABSTRACT}

The objective of this study was to determine the prevalence of Salmonella, Listeria monocytogenes, and fecal coliforms in bulk tank milk in the United States. As part of the NAHMS Dairy 2002 survey, 861 bulk tank milk samples were collected from farms in 21 states. Milk was directly plated on selective agars for direct bacterial enumeration and was enriched in selective broths to increase detection sensitivity. Somatic cell counts (SCC) and standard plate counts (SPC) were also determined. Coliforms were detected in 95\% (818 of 860) of the samples, and the average SCC was 295,000 cells $/ \mathrm{mL}$. Twenty-two samples $(2.6 \%)$ were culture-positive for Salmonella, and 9 serotypes were identified: Montevideo $(\mathrm{n}=7)$, Newport $(\mathrm{n}=4)$, Muenster $(\mathrm{n}=2)$, Meleagridis $(\mathrm{n}=2)$, Cerro $(\mathrm{n}=2), 44: \mathrm{Z36}(\mathrm{Z38})$ $(\mathrm{n}=2)$, Dublin $(\mathrm{n}=1)$, Anatum $(\mathrm{n}=1)$, and 9, 12:nonmotile $(\mathrm{n}=1)$. Listeria monocytogenes was isolated from $56(6.5 \%)$ samples, and serotyping of these isolates yielded 5 serotypes $(1 / 2 a, 1 / 2 b, 3 b, 4 b$, and $4 c)$. Of the L. monocytogenes isolates, $93 \%$ were serotypes $1 / 2 \mathrm{a}, 1 /$ $2 \mathrm{~b}$, and $4 \mathrm{~b}$, the most common human clinical isolates. Regional differences in L. monocytogenes and Salmonella prevalence were observed, but more studies are needed to determine the validity of these differences. There were no apparent relationships between SCC or SPC and incidence of Salmonella or L. monocytogenes. Although the prevalence of $L$. monocytogenes and Salmonella was low, these pathogens represent a potential risk to consumers of raw milk and raw milk products. (Key words: Salmonella, Listeria monocytogenes, coliform, milk)

\footnotetext{
Received December 30, 2003.

Accepted June 2, 2004.

Corresponding author: J. S. Van Kessel; e-mail: jkessel@anri. barc.usda.gov.

*Mention of a trade name, proprietary product, or specific equipment does not constitute a guarantee or warranty by the USDA and does not imply its approval to the exclusion of other products that may be suitable.
}

Abbreviation key: MAC $=$ MacConkey, MOX $=$ Modified Oxford Medium, NAHMS = National Animal Health Monitoring System, SPC = standard plate count, TSA-YE $=$ trypticase soy agar with $0.6 \%$ yeast extract.

\section{INTRODUCTION}

Pasteurization of fluid milk for consumption and production of cheese and other dairy products has been routine in the United States since the 1950s (Ryser, 2001). Pasteurization is very effective against bacterial organisms such as Salmonella, Listeria, and Escherichia coli, so foodborne outbreaks associated with these organisms in pasteurized milk or milk products are rare, and when they do occur, are typically the result of improper pasteurization techniques or postpasteurization contamination. Interstate shipment of raw milk products is illegal; however, raw milk sales are legal in many states. There is a small but growing group of people that consume nonpasteurized milk or milk products; they are sometimes consumed for practical reasons (e.g., dairy farm families), cultural reasons (e.g., soft Mexican-style cheeses), or for perceived health benefits of natural and unprocessed food.

Listeria, Salmonella, and pathogenic E. coli are frequently isolated from dairy cattle and from various locations within dairy farm environments such as water, feed, manure, and bird droppings. Listeriosis and salmonellosis can have serious health implications in calves and cattle, but asymptomatic shedding in feces also occurs (Wesley, 1999; Huston et al., 2002; Kirk et al., 2002; Troutt et al., 2001; Warnick et al., 2001). Most $E$. coli are commensal intestinal organisms that do not cause disease, but a small percentage of $E$. coli are enteropathogenic. Infection with enteropathogenic $E$. coli usually results in mild illness; however, some serotypes are enterohemorrhagic $E$. coli and can lead to hemolytic-uremic syndrome (O'Brien and Kaper, 1998). Escherichia coli O157:H7 is the most common enterohemorrhagic $E$. coli isolated from clinical cases in the 
US and has been the source of several foodborne outbreaks in recent years.

Cattle (beef and dairy) are considered a reservoir of the enteropathogenic $E$. coli O157:H7 (Wallace, 1999). Despite the human pathogenicity of this organism, adult cattle that shed $E$. coli O157:H7 appear to be asymptomatic (Dean-Nystrom et al., 1999). Because Listeria, Salmonella, and E. coli O157:H7 are shed in the feces, it follows that there is a risk of these pathogens entering the bulk tank through fecal contamination.

Milk contamination can also be the result of shedding from the udder. Listeria and Salmonella mastitis are not common; however, shedding of these organisms in milk has been documented (Pearson and Marth, 1990; Jensen et al., 1996; Wesley, 1999; Radke et al., 2002). Therefore, it is assumed that bulk tank milk can also be contaminated with Listeria and Salmonella via intramammary infections. Incidence of $E$. coli mastitis is low (Wilson et al., 1997), and intramammary $E$. coli O157:H7 infections have not been documented.

Several surveys in Canada and the US have detected Salmonella and Listeria in bulk tank milk (Lovett et al., 1987; Rohrbach et al., 1992; Steele et al., 1997; Hassan et al., 2000; Jayarao and Henning, 2001; Murinda et al., 2002b; Muraoka et al., 2003). Incidence of reported Salmonella contamination ranged from $0.17 \%$ in Ontario (Steele et al., 1997) to 8.9\% in Tennessee and Virginia (Rohrbach et al., 1992); Listeria monocytogenes prevalence ranged from $2.73 \%$ in Ontario (Steele et al., 1997) to $12.6 \%$ of farms tested in New York (Hassan et al., 2000). Jayarao and Henning (2001) found 3.8\% of bulk milk samples from South Dakota and Minnesota to be contaminated with shiga toxin-producing $E$. coli, and Steele et al. (1997) reported that $0.87 \%$ of bulk tank samples collected in Ontario contained verotoxigenic $E$. coli. In a survey of 30 dairy farms in east Tennessee, Murinda et al. (2002a) detected E. coli $\mathrm{O} 157: \mathrm{H} 7$ in $0.75 \%$ ( 2 of 268 ) of milk samples. These surveys represent small geographical areas, and no data are available regarding national prevalence of bacterial pathogens in raw milk.

The National Animal Health Monitoring System (NAHMS) conducts national studies on animal health, management, and productivity. The 2002 Dairy Survey was designed to include the collection of a bulk milk sample from participating farms. The objective of this study was to determine the prevalence of $L$. monocytogenes, Salmonella spp., and fecal coliforms in raw, bulk tank milk in the US.

\section{MATERIALS AND METHODS}

\section{Samples}

The milk samples used in this study were collected during the NAHMS Dairy 2002 survey. The USDA,
Table 1. Regions and states.

\begin{tabular}{llc}
\hline Region & States & Number \\
\hline West & CA,CO,ID,NM,TX,WA & 176 \\
Midwest & IL,IN,IA,MI,MN,MO,OH,WI & 361 \\
Northeast & NY,PA,VT & 263 \\
Southeast & FL,KY,TN,VA & 61 \\
\hline
\end{tabular}

National Agricultural Statistics Service provided a sample list frame, and a stratified random sample based on herd size was selected from each of 21 states determined to represent $81 \%$ of dairy herds and $84 \%$ of dairy cows in the US (California, Colorado, Florida, Idaho, Illinois, Indiana, Iowa, Kentucky, Michigan, Minnesota, Missouri, New Mexico, New York, Ohio, Pennsylvania, Tennessee, Texas, Vermont, Virginia, Washington, Wisconsin) (Table 1). Those producers reporting one or more milk cows in inventory on January 1, 2002 were included in Phase I of the NAHMS Dairy 2002 study. In Phase I, National Agricultural Statistics Service enumerators administered a general management questionnaire. For Phase II data collection, which included bulk tank sampling, operations with $\geq 30$ milk cows on January 1, 2002 that participated in Phase I were sampled by federal and state veterinary medical officers or animal health technicians. Samples were collected from February to June 2002. Bulk tank milk (50 $\mathrm{mL}$ ) was aseptically collected from dairy operations and shipped overnight with cold packs to the USDA-ARS laboratory in Beltsville, MD. In some cases, the samples were frozen prior to shipping. Upon arrival at the laboratory, milk samples were immediately partitioned for various analyses.

\section{SCC}

Total SCC were determined on untreated milk samples that were received within $36 \mathrm{~h}$ of collection and were not frozen. Using the method described by Miller et al. (1986), samples were incubated at $60^{\circ} \mathrm{C}$ for 20 min to kill the somatic cells so that the ethidium bromide stain could penetrate the cells and stain the DNA. Samples were run in duplicate on a Fossomatic 90 (Foss North America, Inc., Eden Prairie, MN). Preserved somatic cell control samples were purchased biweekly from DQCI Services, Inc. (Mounds View, MN). Because the somatic cells are killed by the preservative, the controls were incubated at a lower temperature $\left(40^{\circ} \mathrm{C}\right)$ for 30 min prior to analysis (Miller et al., 1986).

\section{Bacteriological Methods}

Standard Plate Count (SPC). Total aerobic bacteria populations were determined following the guide- 
lines of the American Public Health Association (Houghtby et al., 1992). Briefly, milk was spirally plated (50 $\mu \mathrm{L}$; Autoplate 4000; Spiral Biotech, Norwood, MA) in triplicate on Plate Count Agar (BD Diagnostics, Sparks, MD) and incubated at $32^{\circ} \mathrm{C}$ for $48 \mathrm{~h}$. Colonies were counted with an automatic colony counter $(\mathrm{Q}$ Count; Spiral Biotech, Inc.).

Salmonella. Milk (250 $\mu \mathrm{L})$ was plated in triplicate directly onto XLT4 agar (XLT4 agar base with XLT4 supplement; BD Diagnostics) using an Autoplate 4000. Plates were incubated at $37^{\circ} \mathrm{C}$ and scored for presumptive Salmonella colonies (black colonies) at 24 and 48 h. For enrichment of Salmonella, 5 to $10 \mathrm{~mL}$ of milk were added to $90 \mathrm{~mL}$ of tetrathionate broth. The variation in volume was due to variation in available sample; the volume of some of the collected samples was $<50$ $\mathrm{mL}$, so adjustments to the partitioning protocol were necessary. Enrichment bottles were incubated at $37^{\circ} \mathrm{C}$ for $24 \mathrm{~h}$, and then the broth was streaked $(10 \mu \mathrm{L})$ onto XLT4 agar. Plates were incubated and scored as described previously.

Isolated, presumptive Salmonella colonies were transferred from XLT4 plates onto XLT4, Brilliant Green, and L-agar (Lennox Broth base with 1.5\% agar; Gibco Laboratories, Long Island, NY). Colonies that exhibited the Salmonella phenotype (black on XLT4 and pink on Brilliant Green) were preserved for future analysis. Colony biomass was transferred from the Lagar plates to a vial containing $0.5 \mathrm{~mL}$ of a $1: 1$ mixture of Lennox Broth and the $2 \times$ freezing medium for cells of Schleif and Wensink (1981); the isolates were stored at $-80^{\circ} \mathrm{C}$. L-agar slants were inoculated and, after incubation at $37^{\circ} \mathrm{C}$ for $24 \mathrm{~h}$, sent to the National Veterinary Services Laboratories in Ames, IA for serotyping.

Listeria monocytogenes. Milk $(250 \mu \mathrm{L})$ was plated in triplicate directly onto Modified Oxford Medium (MOX) agar (BD Diagnostics) using an Autoplate 4000. Plates were incubated at $37^{\circ} \mathrm{C}$ and scored for presumptive Listeria colonies (esculin hydrolysis, black colonies) at 24 and $48 \mathrm{~h}$. For enrichment of Listeria, 5 to 10 $\mathrm{mL}$ of milk were added to $90 \mathrm{~mL}$ of Modified Listeria Enrichment Broth (BD Diagnostics). Enrichment bottles were incubated at $37^{\circ} \mathrm{C}$ for $48 \mathrm{~h}$, and then the broth was streaked $(10 \mu \mathrm{L})$ onto MOX agar. Plates were incubated and scored as described previously.

Isolated, presumptive Listeria colonies were transferred from MOX plates onto MOX, PALCAM (BD Diagnostics), and trypticase soy agar with $0.6 \%$ yeast extract (TSA-YE). Colonies that exhibited the Listeria phenotype (black on MOX and gray-green with esculin hydrolysis on PALCAM) were preserved for future analysis. Colony biomass was transferred from the TSA-YE plates to $1.5 \mathrm{~mL}$ of tryptic soy broth and incubated at $37^{\circ} \mathrm{C}$ for $48 \mathrm{~h}$. The enriched broth was centrifuged
$(16,000 \times g)$, and the supernatants were discarded. The bacterial pellet was resuspended in $0.5 \mathrm{~mL}$ of $1 \times$ freezing medium for cells of Schleif and Wensink (1981), and the isolates were stored at $-80^{\circ} \mathrm{C}$.

Presumptive Listeria isolates were grown on TSAYE for further testing. Isolates were tested for oxidase with $1 \%$ tetramethyl-p-phenylenediamine dihydrocholride (BD Diagnostics), catalase with 3\% hydrogen peroxide, and gram-stained using a 3-step staining kit (BD Diagnostics). Hemolytic activity was determined by stabbing blood agar (Columbia with 5\% sheep blood; Remel, Lenexa, KS) and incubating at $37^{\circ} \mathrm{C}$ for $48 \mathrm{~h}$. The Christie-Atkins-Munch-Peterson test was performed on each isolate using Staphylococcus aureus Beta Lysin Disks (Remel) and Rhodococcus equi (ATCC 6939; American Type Culture Collection, Manassas, VA) on sheep blood agar.

Additionally, real time PCR was run on DNA extracts of the presumptive Listeria isolates. Isolates were grown in $1.0 \mathrm{~mL}$ of tryptic soy broth at $37^{\circ} \mathrm{C}$ for $48 \mathrm{~h}$. The enriched broth was centrifuged $(16,000 \times g)$, and the supernatants were discarded. The DNA was extracted from the bacterial pellets using a commercially prepared extraction preparation (InstaGene Matrix; BioRad Laboratories, Hercules, CA) following the manufacturer's directions. The DNA preparations $(200 \mu \mathrm{L})$ were stored at $-20^{\circ} \mathrm{C}$ prior to analysis. Real time PCR was run according to the method described by Nogva et al. (2000) using a Mx4000 Multiplex Quantitative PCR System (Stratagene, La Jolla, CA). Amplification reactions $(50 \mu \mathrm{L})$ contained $300 \mathrm{n} M$ of each primer, 250 $\mathrm{n} M$ probe, $12.6 \mu \mathrm{g}$ of BSA, $25 \mu \mathrm{L}$ of TaqMan Master Mix (Applied Biosystems, Foster City, CA), and $5 \mu \mathrm{L}$ of extracted DNA product. The thermal profile used for PCR was $50^{\circ} \mathrm{C}$ for 2 min followed by $95^{\circ} \mathrm{C}$ for $10 \mathrm{~min}$ followed by 40 cycles of $95^{\circ} \mathrm{C}$ for $15 \mathrm{~s}$ and $60^{\circ} \mathrm{C}$ for $60 \mathrm{~s}$. Serotyping of the L. monocytogenes isolates was conducted using a previously described ELISA (Palumbo et al., 2003).

Fecal coliforms. Milk (50 $\mu \mathrm{L} \times 1 ; 250 \mu \mathrm{L} \times 3)$ was plated directly onto MacConkey (MAC) agar (Remel) using an Autoplate 4000. Plates were incubated at $42.5^{\circ} \mathrm{C}$ for $18 \mathrm{~h}$ and scored for colonies (pink colonies with precipitate). For enrichment of $E$. coli, 5 to 10 $\mathrm{mL}$ of milk were added to $90 \mathrm{~mL}$ of EC Broth (BD Diagnostics). Enrichment bottles were incubated at $42.5^{\circ} \mathrm{C}$ for $48 \mathrm{~h}$, and then the broth was streaked (10 $\mu \mathrm{L})$ onto MAC agar and incubated at $42.5^{\circ} \mathrm{C}$ for $18 \mathrm{~h}$. Plates were scored as described previously; isolates were transferred onto MAC agar, Simmons' Citrate Agar (BD Diagnostics), and L-agar and incubated at $37^{\circ} \mathrm{C}$ for $18 \mathrm{~h}$. Isolates were screened for the $E$. coli phenotype (lactose positive, citrate negative, nonswarming). 


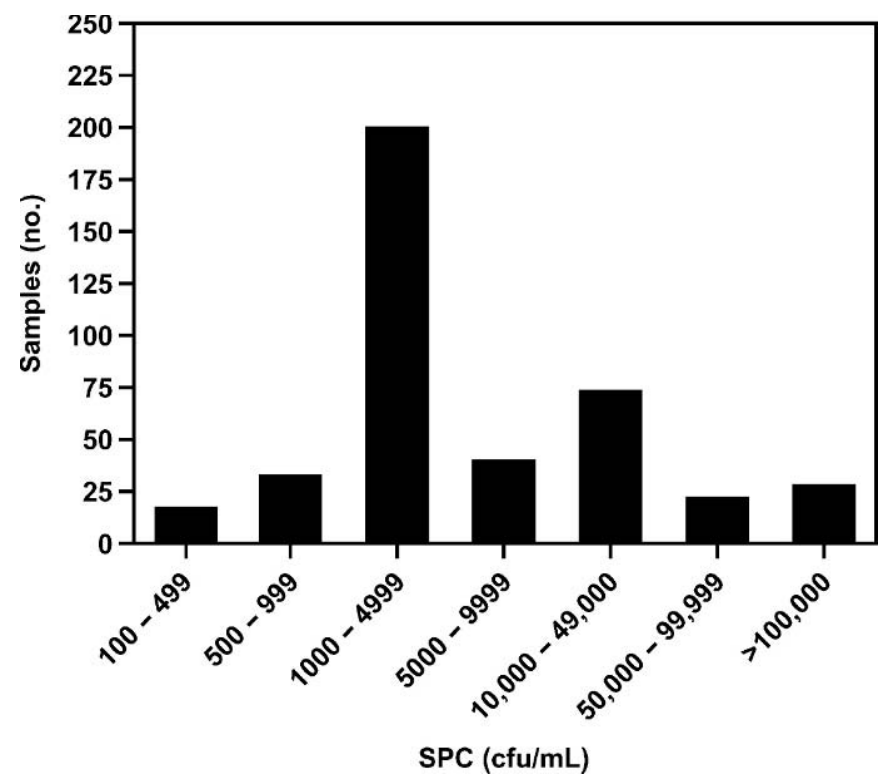

Figure 1. Frequency distribution of standard plate counts (SPC) for a subset of bulk milk samples from the National Animal Health Monitoring System Dairy 2002 study $(\mathrm{n}=419)$ that were received within $36 \mathrm{~h}$ of collection and not frozen.

\section{RESULTS}

A total of 861 bulk tank milk samples were received between February 25 and June 30, 2002. Some samples $(\mathrm{n}=158)$ could not be shipped to the laboratory immediately after collection and were frozen prior to shipment. When samples $(n=114)$ could not be processed on the day they were received at the laboratory, they were frozen prior to analysis. The remainder of the samples $(n=589)$ were analyzed immediately upon arrival.

Standard plate counts and SCC were only considered valid when the milk samples were received within $36 \mathrm{~h}$ of collection; intervals $>36 \mathrm{~h}$ resulted in thawed freezer packs and conditions conducive for bacterial growth. A total of 419 samples met this criterion. The SPC of this subset of samples ranged from $102 \mathrm{cfu} / \mathrm{mL}$ to $>1 \times 10^{5}$ $\mathrm{cfu} / \mathrm{mL}$. Figure 1 shows the distribution of SPC among the raw milk samples. Almost one-half $(48 \%)$ of the samples fell within 1000 to $4999 \mathrm{cfu} / \mathrm{mL}$. Of the remainder, $40 \%$ of the samples had $>5000 \mathrm{cfu} / \mathrm{mL}$, and approximately $12 \%$ of the samples had $<1000 \mathrm{cfu} / \mathrm{mL}$. The SPC is used in the dairy industry as a measure of milk quality and is a measurement of aerobic bacterial contamination. The SPC limit for Grade A milk in the US is $100,000 \mathrm{cfu} / \mathrm{mL}$, and 29 samples $(6.9 \%)$ in this study exceeded this limit.

The distribution of SCC among the milk samples ( $\mathrm{n}=$ 419) appeared to be skewed but normal (Figure 2), with an average of 295,000 cells $/ \mathrm{mL}$. Bulk tank SCC ranged from 16,000 to $1,515,000$ cells $/ \mathrm{mL}$ with most $(97.8 \%)$ of

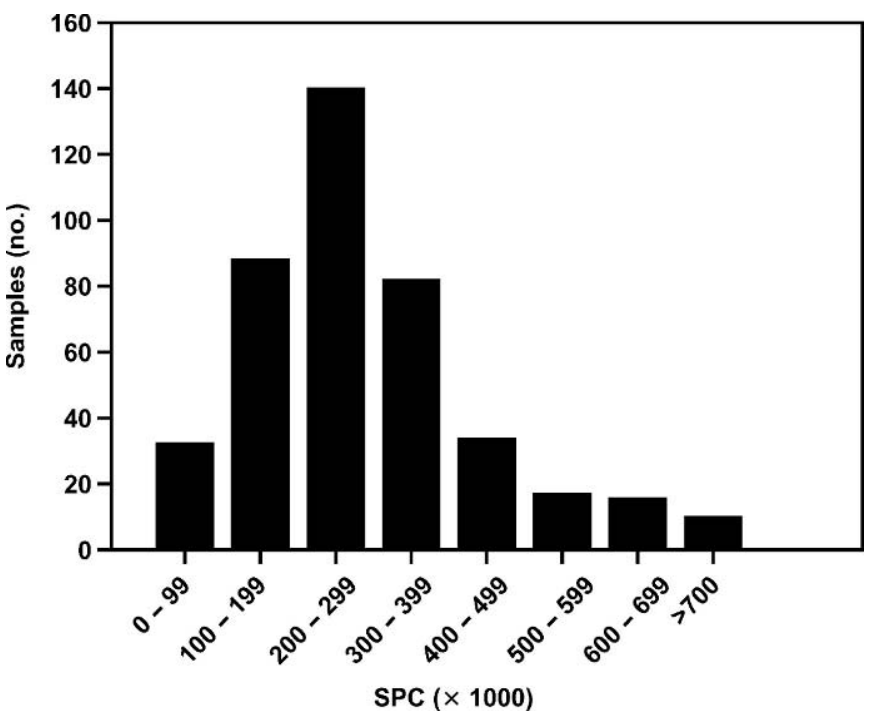

Figure 2. Frequency distribution of SCC for a subset of bulk milk samples from the National Animal Health Monitoring System Dairy 2002 study $(n=419)$ that were received within $36 \mathrm{~h}$ of collection and not frozen.

the samples having a SCC of less than the US regulatory limit of 750,000 cells/mL (US Dep. Health and Human Services, 2004). A reduction in the US regulatory limit to 400,000 cell $\mathrm{s} / \mathrm{mL}$ has been proposed by several industry groups (Norman et al., 2000), and approximately $82 \%(\mathrm{n}=342)$ of the milk samples had an SCC below this level.

When milk was directly plated onto selective media without enrichment, presumptive Salmonella isolates were obtained from 5 samples. Enrichment in tetrathionate broth followed by plating resulted in presumptive Salmonella isolation from 19 additional milk samples. Therefore, there were 24 presumptive Salmonella culture-positive milk samples. When isolates from these 24 samples were serotyped, 22 were confirmed as Salmonella. Therefore, $2.6 \%$ (22 of 861 ) of the bulk milk samples were contaminated with Salmonella. Nine serotypes were identified: Salmonella Montevideo $(\mathrm{n}=7)$, Salmonella Newport ( $\mathrm{n}=4)$, Salmonella Muenster ( $\mathrm{n}=$ 2), Salmonella Meleagridis $(\mathrm{n}=2)$, Salmonella Cerro $(\mathrm{n}=2)$, Salmonella 44:Z36 (Z38) ( $=2)$, Salmonella Dublin ( $\mathrm{n}=1)$, Salmonella Anatum ( $\mathrm{n}=1)$, and Salmonella 9, 12:nonmotile $(\mathrm{n}=1)$.

Eleven of the Salmonella-positive samples were received within $36 \mathrm{~h}$ of sampling and were not frozen prior to analysis. Salmonella was isolated directly from 2 of these samples, and, in both cases, Salmonella was detected at approximately $4 \mathrm{cfu} / \mathrm{mL}$. For the 9 samples where Salmonella was only detected after enrichment, initial Salmonella population cannot be determined specifically but was at least $1 \mathrm{cfu}$ per $10 \mathrm{~mL}$ of milk 
Table 2. Serotypes of the Listeria monocytogenes isolates obtained from raw milk.

\begin{tabular}{lc}
\hline Serotype & Isolates (no.) \\
\hline $1 / 2 \mathrm{a}$ & 26 \\
$1 / 2 \mathrm{~b}$ & 18 \\
$3 \mathrm{~b}$ & 2 \\
$4 \mathrm{~b}$ & 10 \\
$4 \mathrm{c}$ & 2 \\
\hline
\end{tabular}

but less than $40 \mathrm{cfu}$ per $10 \mathrm{~mL}$ of milk. The remaining 11 Salmonella-positive samples were either frozen prior to analysis or were not received at the laboratory within $36 \mathrm{~h}$ of collection. Therefore, no conclusions can be made concerning the level of contamination in these samples.

Presumptive Listeria were isolated from 90 (10.4\%) raw milk samples using traditional culture techniques. Based on Gram stain (positive), oxidase test (negative), catalase test (positive), hemolytic profiles, and real time PCR analysis, $56(6.5 \%)$ of these presumptive isolates were confirmed as L. monocytogenes. Isolation was achieved from direct plating of 18 samples, indicating the presence of $L$. monocytogenes at a minimum of 4 $\mathrm{cfu} / \mathrm{mL}$. The population of $L$. monocytogenes in the remaining 38 samples was below our direct detection limit, and L. monocytogenes was only isolated after enrichment with Modified Listeria Enrichment Broth.

Thirty-two of the L. monocytogenes-positive samples were received within $36 \mathrm{~h}$ of sampling and were not frozen prior to analysis. Listeria monocytogenes was isolated without enrichment from 11 of these samples, and the population of $L$. monocytogenes in these milk samples ranged from 1 to $37 \mathrm{cfu} / \mathrm{mL}$. The 25 samples from which Listeria was isolated only after enrichment theoretically contained at least $1 \mathrm{cfu}$ per $10 \mathrm{~mL}$ of milk but $<40 \mathrm{cfu}$ per $10 \mathrm{~mL}$ of milk. The remaining $24 \mathrm{~L}$. monocytogenes-positive samples were either frozen prior to analysis or were not received at the laboratory within $36 \mathrm{~h}$ of collection. Therefore, no conclusions can be made concerning the level of contamination in these samples.

Serotyping of the L. monocytogenes isolates yielded 5 different serotypes (Table 2). There were 12 samples from which $L$. monocytogenes was isolated from both direct plating and enriching protocols. In 9 of these samples, direct plating and enrichment yielded the same serotypes. However, multiple serotypes were isolated from each of 3 samples. Serotypes $1 / 2 b$ and $3 b, 1 /$ $2 \mathrm{a}$ and $4 \mathrm{c}$, and $1 / 2 \mathrm{a}$ and $4 \mathrm{~b}$ were isolated from samples that came from farms in Wisconsin, Vermont, and Connecticut, respectively. Serotypes $1 / 2 \mathrm{a}$ and $1 / 2 \mathrm{~b}$ were equi-prevalent in the West, while $1 / 2 \mathrm{~b}$ predominated in the Midwest, and 1/2a predominated in the Northeast. None of the L. monocytogenes isolated from the South-

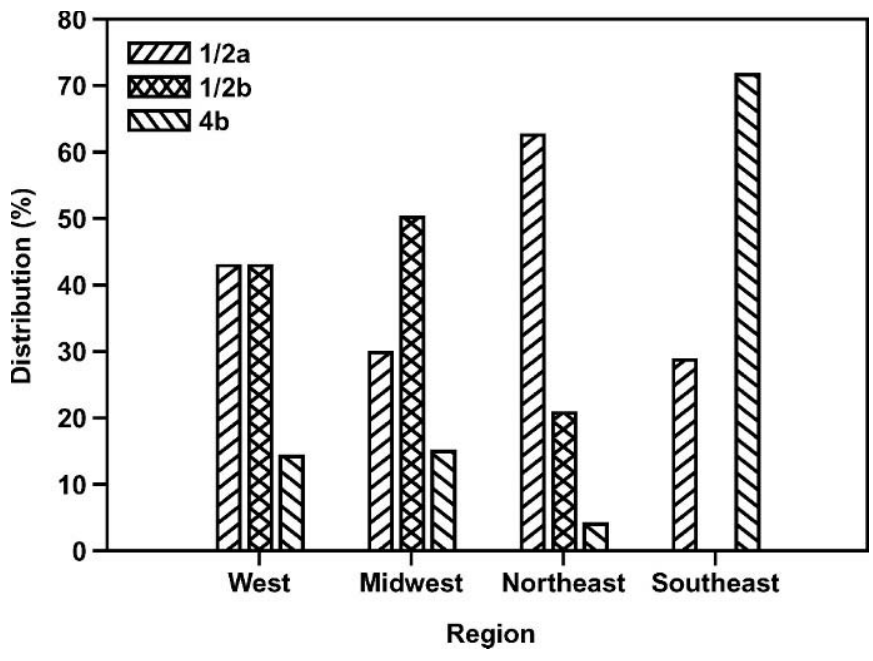

Figure 3. Regional distribution of serotypes of Listeria monocytogenes isolates from raw milk samples collected during the National Animal Health Monitoring System Dairy 2002 study $(\mathrm{n}=62)$.

east were serotype $1 / 2 \mathrm{~b}$, and $4 \mathrm{~b}$ was the predominant serotype isolated from samples in this region (Figure 3 ).

The prevalence of Listeria, L. monocytogenes, and Salmonella within each of 4 regions (Table 1 ) in the US are presented in Figure 4. Listeria was approximately twice as prevalent in the Southeast (18\%) and Northeast $(13.7 \%)$ compared with the West $(8.0 \%)$ and Midwest ( $8.0 \%$ ); the same trend was observed for $L$. monocytogenes $(9.8,9.1,4.0$, and 5.3\%, respectively). However, Salmonella was not isolated from any of the Southeast bulk milk samples and from only $1.1 \%$ of the Northeast

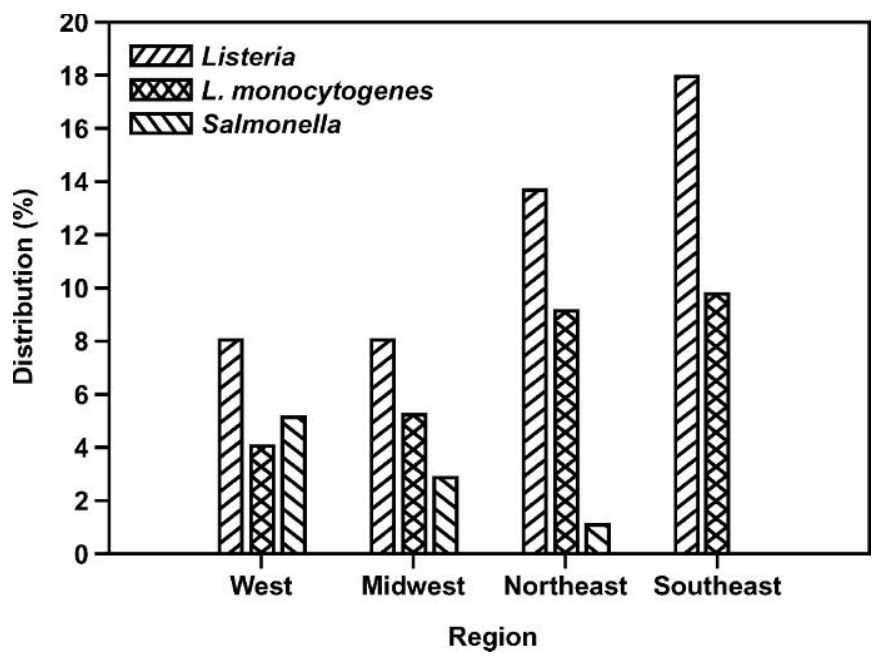

Figure 4. Regional distribution of Listeria $(\mathrm{n}=860)$, Listeria monocytogenes $(\mathrm{n}=860)$, and Salmonella $(\mathrm{n}=861)$ in bulk milk samples from the National Animal Health Monitoring System Dairy 2002 study. 


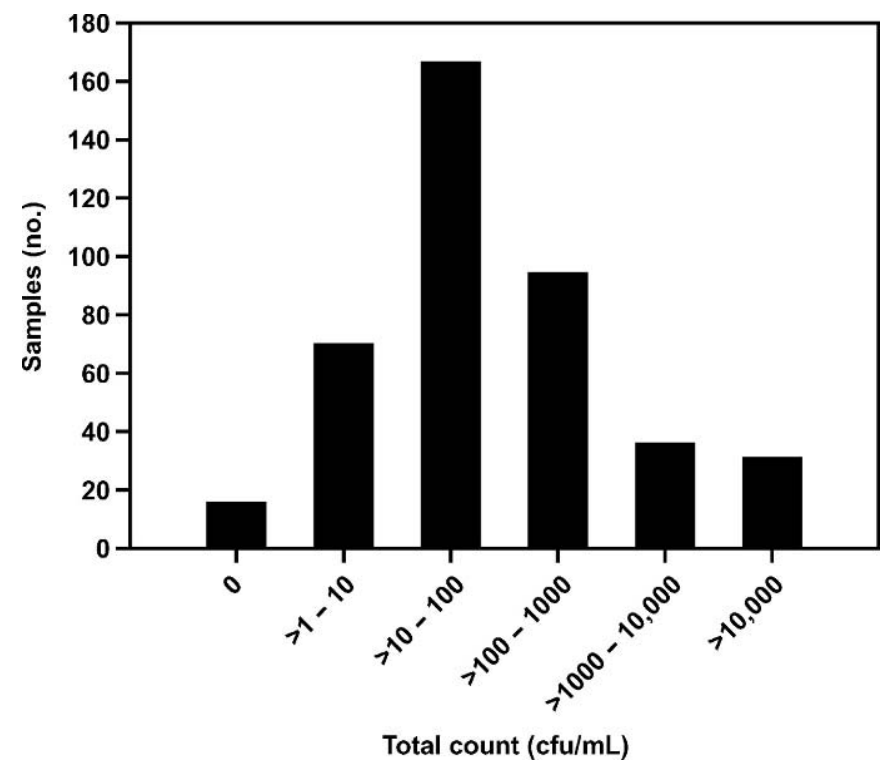

Figure 5. Frequency distribution of fecal coliform concentration for a subset of bulk milk samples from the National Animal Health Monitoring System Dairy 2002 study $(n=419)$ that were received within $36 \mathrm{~h}$ of collection and not frozen.

samples. In contrast, 5.1 and $2.8 \%$ of the samples from the West and Midwest, respectively, were contaminated with Salmonella.

The standard incubation temperature for fecal coliform determination in water is $44.5^{\circ} \mathrm{C}$ (American Public Health Association, 1998). Published data suggest that E. coli $\mathrm{O} 157: \mathrm{H} 7$ does not grow well at this temperature. Because we were interested in eventually screening the preserved $E$. coli isolates for enteropathogenic strains, we decreased the incubation temperature to $42.5^{\circ} \mathrm{C}$. Previous work in this laboratory with $E$. coli O157:H7 isolates showed that they grew well at this temperature (data not shown).

Fecal coliforms were detected in $95 \%$ (818 of 860) of all collected milk samples. When isolated colonies from enrichment cultures were transferred onto MAC agar, Simmons' Citrate agar, and L agar, phenotypes typical of $E$. coli (lactose positive, citrate negative, nonswarming) were observed in $93 \%$ (798 of 859) of the samples. When considering only the subset of samples that were received within $36 \mathrm{~h}$ of collection and not frozen, fecal coliforms were detected in $96.2 \%$ (403 of 419) of the samples. The distribution of fecal coliforms appeared normal (Figure 5), and approximately $40 \%$ of the samples had coliform populations between 10 and $100 \mathrm{cfu} /$ $\mathrm{mL}$. Distributions of coliform populations were similar across regions (data not shown).

\section{DISCUSSION}

Dairy products account for a small percentage of foodborne illness in the US, and many of these out- breaks are due to the consumption of raw milk and raw milk products (el-Gazzar and Marth, 1992; Ryser, 2001). Clearly, raw milk consumption poses some, as yet undefined, level of risk, but this is not the only reason for concern. In recent years, the safety of the food supply has become a focal point for public concern. Consumers are more aware of the potential for foodborne pathogens and are concerned that their food is 'clean and wholesome.' Public perception of food quality is critical in the marketing of any product. Therefore, even though pasteurization is an effective control method for bacterial pathogens, it is important to maintain high preprocessing standards. Additionally, raw milk contaminated with zoonotic pathogens might provide a reservoir for recontamination at milk processing plants.

Based on our results, it appears that the national (US) average of Salmonella and L. monocytogenes contamination in bulk tank milk is low (2.6 and 6.5\%, respectively). Previously reported surveys of bulk tank milk in the United States and Canada have shown the prevalence of Salmonella and L. monocytogenes to range from 0.17 to $6.1 \%$ and from 2.7 to $12.6 \%$, respectively (Rohrbach et al., 1992; Steele et al., 1997; Hassan et al., 2000; Jayarao and Henning, 2001; Murinda et al., 2002b; Muraoka et al., 2003). The disparate levels of contamination in these localized studies might have been due to variations in regions or to variations in sampling and detection techniques. For example, in a survey of dairy farms in New York, Hassan et al. (2000) sampled inline milk filters; most other studies were conducted with milk samples. Hassan et al. (2000) found a high prevalence of $L$. monocytogenes (12.6\%) but a relatively low prevalence of Salmonella (1.5\%).

The results of this NAHMS survey suggest that Listeria contamination was more frequent in bulk milk from the eastern regions of the US than from the West and Midwest regions. Salmonella contamination, however, was more frequent in the West and Midwest regions than the Northeast and Southeast regions. Although trends toward regional differences were evident, there were relatively low numbers of positive samples in this study; more samples would be needed to determine the validity of these regional differences. In contrast to the bulk tank results of this survey, Salmonella was isolated from more operations in the Southeast than from any of the other regions when fecal samples were collected over a 6-mo period as part of the NAHMS Dairy 2002 survey (USDA, 2003b). Additionally, Wells et al. (2001) reported regional differences in Salmonella shedding at the herd level as well as at dairy cull cow markets. In that case, the highest shedding prevalence was in the South. Those researchers also point out the need for caution in drawing conclusions from these dif- 
ferences because of herd size and seasonal differences. Lovett et al. (1987) also found regional differences in L. monocytogenes prevalence in bulk milk; the incidence varied from $0 \%$ in California to $7 \%$ in Massachusetts.

There are $>2000$ known serotypes of $S$. enterica. The most common serotypes isolated from the milk samples in this study were Montevideo (31.8\%), Newport (18.2\%), Muenster (9.1\%), Meleagridis (9.1\%), and Cerro (9.1\%). This profile is somewhat different than results of the NAHMS Dairy 1996 study (USDA, 1998; Wells et al., 2001), which showed fecal shedding of Salmonella in $5.4 \%$ of cows. The most common serotypes isolated from the fecal samples in that study were Montevideo (21.5\%), Cerro (13.3\%), Kentucky (8.5\%), Menhaden (7.7\%), Anatum (6.1\%), Meleagridis (6.1\%), Muenster (4.7\%), and Mbandaka (4.6\%). Since 1996, there has been a rise in the incidence of $S$. enterica Newport, both in humans (Joyce et al., 2000; Zansky et al., 2002) and in animals (USDA, 2002). Although the most common salmonellae that cause disease in humans (US) are S. enterica Typhimurium, Enteritidis, and Heidelburg, all Salmonella are potentially pathogenic. Unlike most Salmonella isolates, Newport isolates frequently exhibit resistance to multiple antimicrobials, and this characteristic dramatically increases the potential infection risks associated with this organism.

A common source of $L$. monocytogenes infection for dairy cows is poorly preserved silage, but listeriae are also commonly found in the environment (Wesley, 1999) and have also been isolated from soil, decaying foliage, and bird and wildlife feces (Weis and Seeliger, 1975). Listeria monocytogenes is the only listeria that is pathogenic for healthy humans, and there appears to be substantial virulence variation between serotypes. Wiedmann et al. (1997) suggested that some serotypes might exhibit host specificity for humans and animals. Of the 13 known $L$. monocytogenes serotypes, $1 / 2 \mathrm{a}, 1 / 2 \mathrm{~b}$, and $4 \mathrm{~b}$ are the most common human clinical isolates (Tappero et al., 1995). In this study, $93 \%$ of the L. monocytogenes isolates obtained from the raw milk were serotyped as $1 / 2 \mathrm{a}, 1 / 2 \mathrm{~b}$, or $4 \mathrm{~b}$ (Table 2 ), which suggests that consumption of the raw milk from which these isolates were obtained would have posed a potential human health risk. Additionally, production of cheese from infected milk may lead to bacterial growth and a highly contaminated product. Such cheeses have been implicated in outbreaks of listeriosis (Anonymous, 1985, 2001), although it is not known at what point in production contamination occurred.

There was more variability in $L$. monocytogenes serotypes in this study than in previous reports from the US (Muraoka et al., 2003) and Sweden (Waak et al., 2002). In a survey of farm bulk tanks and dairy plant receiving tanks in Sweden, Waak et al. (2002) obtained $65 \mathrm{~L}$. monocytogenes isolates, and these isolates were primarily serotype 1/2a. Muraoka et al. (2003) tested bulk milk samples from 474 herds in Washington, Oregon, and Idaho. In 2 separate samplings, they found $L$. monocytogenes in 4.9 and $7.0 \%$ of the herds. All of the isolates from the first collection were serotype $1 / 2 \mathrm{a}$, and $82 \%$ of the isolates from the second collection were serotype 1/2a. In the present study, L. monocytogenes was isolated from only one sample from these 3 states, but it was also serotyped as 1/2a. The varied distribution of $L$. monocytogenes serotypes with respect to region (Figure 3) may reflect local movement and distribution of animals, feedstuffs, and people.

Fecal coliforms are often used as an indicator of fecal contamination and the potential risk of zoonotic pathogens. Fecal coliforms such as nonpathogenic E. coli are prevalent in the digestive tracts of cattle (Diez-Gonzalez et al., 1998; Van Kessel et al., 2002; Laven et al., 2003), and the assumption is that there is a correlation between the presence of fecal coliforms and pathogenic organisms. Fecal coliforms such as $E$. coli can get into bulk tank milk either via intramammary secretion or via fecal contamination of the udder or milking equipment. In the present study, only $7 \%$ of the milk samples were identified as not being contaminated with fecal coliforms $(<1 \mathrm{cfu} / 10 \mathrm{~mL})$. Complete elimination of fecal matter entering the milk is very difficult, but the data from this study show that there is a large variation in levels of bulk milk fecal coliform contamination (Figure $5)$. There are no data to indicate that, if pathogenic $E$. coli were present in the feces, distribution of these organisms would be any different than that of fecal coliforms. In recent years, it has become more evident that pathogenic strains of $E$. coli such as $\mathrm{O} 157: \mathrm{H} 7$ are present at some level on a significant number of dairy farms (Zhao et al., 1995; Faith et al., 1996; Byrne et al., 2003). Results of the NAHMS Dairy 2002 study showed that $38.5 \%$ of dairy operations had at least one fecal sample test positive for $E$. coli O157 (USDA, 2003a). It would follow then that milk containing high levels of fecal coliforms is also at risk for being contaminated with pathogenic $E$. coli.

The average SCC for milk samples collected in this study $(295,000$ cells $/ \mathrm{mL})$ was consistent with the national SCC average of 313,000 cells $/ \mathrm{mL}$ for herds enrolled in DHI during 2002 (Miller and Norman, 2003). The National Conference on Interstate Milk Shipments sets the legal SCC limit for Grade A milk production in the US at 750,000 cells $/ \mathrm{mL}$, and bulk tank SCC have long been used as an indicator for udder health (Jayarao et al., 2001). Assuming that SCC is also an indicator of management level, there may be the potential for a relationship between SCC and zoonotic pathogen prev- 
alence. However, based on the results of this study, there did not appear to be a relationship between SCC and Salmonella or L. monocytogenes contamination. The average SCC of the samples identified from the 419-sample subset as positive for Salmonella (11 samples) and $L$. monocytogenes (31 samples) was 301,000 and 298,000 cells $/ \mathrm{mL}$, respectively. One outlier was excluded from the $L$. monocytogenes average because of a SCC of 1,515,000 cells/mL. Similarly, there was no apparent relationship between Salmonella or L. monocytogenes prevalence and SPC (data not shown).

In summary, microbial analysis of 861 bulk tank milk samples taken during the NAHMS 2002 dairy survey indicated that salmonellae and $L$. monocytogenes were present in 2.6 and $6.5 \%$ of the samples, respectively. In all cases, the pathogens were present at low levels. Although the prevalence of these organisms was low, inappropriate handling of raw milk could result in bacterial growth and substantially increase the potential risk to consumers of raw milk and raw milk products. This highlights the need for vigilance in maintaining hygienic conditions in milking and processing environments. There is no apparent relationship between SCC or SPC and the presence of Salmonella or L. monocytogenes. There may be regional differences in prevalence of individual zoonotic bacteria, and this may warrant further study.

\section{ACKNOWLEDGMENTS}

The authors acknowledge the excellent technical assistance from Thomas Jacobs Jr., Sumit Dua, Sebastian Bottero, and Crystal Rice. We also thank Max Paape for assistance with SCC analysis.

\section{REFERENCES}

American Public Health Association. 1998. Standard Methods for the Examination of Water and Wastewater. American Public Health Association, Washington, DC.

Anonymous. 1985. Listeriosis outbreak associated with Mexican-style cheese-California. MMWR Morb. Mortal. Wkly. Rep. 34:357359.

Anonymous. 2001. Outbreak of listeriosis associated with homemade Mexican-style cheese-North Carolina, October 2000-January 2001. MMWR Morb. Mortal. Wkly. Rep. 50:560-562.

Byrne, C. M., I. Erol, J. E. Call, C. W. Kaspar, D. R. Buege, C. J. Hiemke, P. J. Fedorka-Cray, A. K. Benson, F. M. Wallace, and J. B. Luchansky. 2003. Characterization of Escherichia coli O157:H7 from downer and healthy dairy cattle in the upper Midwest region of the United States. Appl. Environ. Microbiol. 69:4683-4688.

Dean-Nystrom, E. A., B. T. Bosworth, A. D. O'Brien, and H. W. Moon. 1999. Bovine infection with Escherichia coli O157:H7. Pages 5158 in Escherichia coli O157:H7 in Farm Animals. C. S. Stewart and H. J. Flint, ed. CABI Publishing, New York.

Department U. S. Health and Human Services, US Food and Drug Administration Center for Food Safety \& Applied Nutrition. 2004. Grade "A" Pasteurized Milk Ordinance (PMO), 2001 revision. DHHS-FDA-CFSAN. Available: http://www.cfsan.fda.gov/ ear/ pmo01-2.html. Accessed May 5, 2004.
Diez-Gonzalez, F., T. R. Callaway, M. G. Kizoulis, and J. B. Russell. 1998. Grain feeding and the dissemination of acid-resistant Escherichia coli from cattle. Science 281:1666-1668.

el-Gazzar, F. E., and E. H. Marth. 1992. Salmonellae, salmonellosis, and dairy foods: A review. J. Dairy Sci. 75:2327-2343.

Faith, N. G., J. A. Shere, R. Brosch, K. W. Arnold, S. E. Ansay, M.S. Lee, J. B. Luchansky, and C. W. Kaspar. 1996. Prevalence and clonal nature of Escherichia coli $\mathrm{O} 157: \mathrm{H} 7$ on dairy farms in Wisconsin. Appl. Environ. Microbiol. 62:1519-1525.

Hassan, L., H. O. Mohammed, P. L. McDonough, and R. N. Gonzalez. 2000. A cross-sectional study on the prevalence of Listeria monocytogenes and Salmonella in New York dairy herds. J. Dairy Sci. 83:2441-2447.

Houghtby, G. A., L. J. Maturin, and E. K. Koenig. 1992. Microbiological count methods. Pages 213-246 in Standard Methods for Examination of Dairy Products. R. T. Marshall, ed. American Public Health Association, Washington, DC.

Huston, C. L., T. E. Wittum, B. C. Love, and J. E. Keen. 2002. Prevalence of fecal shedding of Salmonella spp in dairy herds. J. Am. Vet. Med. Assoc. 220:645-649.

Jayarao, B. M., and D. R. Henning. 2001. Prevalence of foodborne pathogens in bulk tank milk. J. Dairy Sci. 84:2157-2162.

Jayarao, B. M., S. R. Pillai, D. R. Wolfgang, D. R. Griswold, and L. J. Hutchinson. 2001. Herd level information and bulk tank milk analysis: Tools for improving milk quality and herd udder health. The Bovine Pract. 35:23-35.

Jensen, N. E., F. M. Aarestrup, J. Jensen, and H. C. Wegener. 1996. Listeria monocytogenes in bovine mastitis. Possible implication for human health. Int. J. Food Microbiol. 32:209-216.

Joyce, K., P. Mshar, J. Sexton, A. Goddard, P. Fedorka-Cray, S. Rossiter, R. Tauxe, T. Barrett, and K. Petersen. 2000. Emergence of a multidrug-resistant strain of Salmonella serotype Newport in the United States: NARMS 1997-1999. 2nd Int. Conf. Emerging Infect. Dis., NARMS Working Group, Atlanta, GA. CDC, Atlanta, GA.

Kirk, J. H., C. A. Holmberg, and J. S. Jeffrey. 2002. Prevalence of Salmonella spp in selected birds captured on California dairies. J. Am. Vet. Med. Assoc. 220:359-362.

Laven, R. A., A. Ashmore, and C. S. Stewart. 2003. Escherichia coli in the rumen and colon of slaughter cattle, with particular reference to $E$. coli O157. Vet. J. 165:78-83.

Lovett, J., D. W. Francis, and J. M. Hunt. 1987. Listeria monocytogenes in raw milk: Detection, incidence, and pathogenicity. J. Food Prot. 50:188-192.

Miller, R. H., and H. D. Norman. 2003. Somatic cell counts of milk from Dairy Herd Improvement herds during 2002. SCC4(2-03). USDA:ARS:BARC:AIPL, Beltsville, MD. Available: http://aipl.arsusda.gov/publish/dhi/current/sccrpt.htm. Accessed May 5, 2004.

Miller, R. H., M. J. Paape, and J. C. Acton. 1986. Comparison of milk somatic cell counts by Coulter and Fossomatic Counters. J. Dairy Sci. 69:1942-1946.

Muraoka, W., C. Gay, D. Knowles, and M. Borucki. 2003. Prevalence of Listeria monocytogenes subtypes in bulk milk of the Pacific Northwest. J. Food Prot. 66:1413-1419.

Murinda, S. E., L. T. Nguyen, S. J. Ivey, B. E. Gillespie, R. A. Almeida, F. A. Draughon, and S. P. Oliver. 2002a. Prevalence and molecular characterization of Escherichia coli O157:H7 in bulk tank milk and fecal samples from cull cows: A 12-month survey of dairy farms in east Tennessee. J. Food Prot. 65:752-759.

Murinda, S. E., L. T. Nguyen, S. J. Ivey, B. E. Gillespie, R. A. Almeida, F. A. Draughon, and S. P. Oliver. 2002b. Molecular characterization of Salmonella spp. isolated from bulk tank milk and cull dairy cow fecal samples. J. Food Prot. 65:1100-1105.

Nogva, H. K., K. Rudi, K. Naterstad, A. Holck, and D. Lillehaug. 2000. Application of 5'-nuclease PCR for quantitative detection of Listeria monocytogenes in pure cultures, water, skim milk, and unpasteurized whole milk. Appl. Environ. Microbiol. 66:42664271.

Norman, H. D., R. H. Miller, J. R. Wright, and G. R. Wiggans. 2000. Herd and state means for somatic cell count from dairy herd improvement. J. Dairy Sci. 83:2782-2788. 
O'Brien, A. D., and J. B. Kaper. 1998. Shiga toxin-producing Escherichia coli: Yesterday, today, and tomorrow. Pages 1-11 in Escherichia coli $\mathrm{O} 157: \mathrm{H} 7$ and other shiga toxin-producing $E$. coli strains. J. B. Kaper and A. D. O'Brien, ed. ASM Press, Washington, DC.

Palumbo, J. D., M. K. Borucki, R. E. Mandrell, and L. Gorski. 2003. Serotyping of Listeria monocytogenes by enzyme-linked immunosorbent assay and identification of mixed-serotype cultures by colony immunoblotting. J. Clin. Microbiol. 41:564-571.

Pearson, L. J., and E. H. Marth. 1990. Listeria monocytogenesThreat to a safe food supply: A review. J. Dairy Sci. 73:912-928.

Radke, B. R., M. McFall, and S. M. Radostits. 2002. Salmonella Muenster infection in a dairy herd. Can. Vet. J. 43:443-453.

Rohrbach, B. W., F. A. Draughon, P. M. Davidson, and S. P. Oliver. 1992. Prevalence of Listeria monocytogenes, Campylobacter jejuni, Yersinia enterocolitica, and Salmonella in bulk tank milk: Risk factors and risk of human exposure. J. Food Prot. 55:93-97.

Ryser, E. T. 2001. Public Health Concerns. Pages 397-545 in Applied Dairy Microbiology. E. H. Marth and J. L. Steele, ed. Marcel Dekker, Inc., New York.

Schleif, R. F., and P. C. Wensink. 1981. Practical Methods in Molecular Biology. Springer-Verlag, New York.

Steele, M. L., W. B. McNab, C. Poppe, M. W. Griffiths, S. Chen, S. A. Degrandis, L. C. Fruhner, C. A. Larkin, J. A. Lynch, and J. A. Odumeru. 1997. Survey of Ontario bulk tank raw milk for food-borne pathogens. J. Food Prot. 60:1341-1346.

Tappero, J. W., A. Schuchat, K. A. Deaver, L. Mascola, and J. D. Wenger. 1995. Reduction in the incidence of human listeriosis in the United States. Effectiveness of prevention efforts? The Listeriosis Study Group. JAMA 273:1118-1122.

Troutt, H. F., J. C. Galland, B. I. Osburn, R. L. Brewer, R. K. Braun, J. A. Schmitz, P. Sears, A. B. Childers, E. Richey, E. Mather, M. Gibson, K. Murthy, and A. Hogue. 2001. Prevalence of Salmonella spp in cull (market) dairy cows at slaughter. J. Am. Vet. Med. Assoc. 219:1212-1215.

USDA. 1998. E. coli O157 and Salmonella: Status on U.S. Dairy Operations. USDA:APHIS:VS, CEAH, National Animal Health Monitoring System, Fort Collins, CO. \#N286.598.

USDA. 2002. What Veterinarians and Producers Should Know About Multidrug-Resistant Salmonella Newport. USDA:APHIS:VS, CEAH, Fort Collins, CO. \#N363.0902.

USDA. 2003a. Escherichia coli 0157 on U.S. Dairy Operations. USDA:APHIS:VS:CEAH, Fort Collins, CO. \#N404.1203.
USDA. 2003b. Salmonella and Campylobacter on U.S. Dairy Operations. USDA:APHIS:VS:CEAH, Fort Collins, CO. \#N401.1203.

Van Kessel, J. S., P. C. Nedoluha, A. Williams-Campbell, R. L. Baldwin, and K. R. McLeod. 2002. Effects of ruminal and postruminal infusion of starch hydrolysate or glucose on the microbial ecology of the gastrointestinal tract in growing steers. J. Anim. Sci. 80:3027-3034.

Waak, E., W. Tham, and M. L. Danielsson-Tham. 2002. Prevalence and fingerprinting of Listeria monocytogenes strains isolated from raw whole milk in farm bulk tanks and in dairy plant receiving tanks. Appl. Environ. Microbiol. 68:3366-3370.

Wallace, J. S. 1999. The ecological cycle of Escherichia coli O157:H7. Pages 195-223 in Escherichia coli O157 in Farm Animals. C. S. Stewart and H. J. Flint, ed. CABI Publishing, New York.

Warnick, L. D., L. M. Crofton, K. D. Pelzer, and M. J. Hawkins. 2001. Risk factors for clinical salmonellosis in Virginia, USA cattle herds. Prev. Vet. Med. 49:259-275.

Weis, J., and H. P. Seeliger. 1975. Incidence of Listeria monocytogenes in nature. Appl. Microbiol. 30:29-32.

Wells, S. J., P. J. Fedorka-Cray, D. A. Dargatz, K. Ferris, and A. Green. 2001. Fecal shedding of Salmonella spp. by dairy cows on farm and at cull cow markets. J. Food Prot. 64:3-11.

Wesley, I. V. 1999. Listeriosis in animals. Pages 39-73 in Listeria, Listeriosis, and Food Safety. E. T. Ryser and E. H. Marth, ed. Marcel Dekker, Inc., New York.

Wiedmann, M., J. L. Bruce, C. Keating, A. E. Johnson, P. L. McDonough, and C. A. Batt. 1997. Ribotypes and virulence gene polymorphisms suggest three distinct Listeria monocytogenes lineages with differences in pathogenic potential. Infect. Immun. 65:2707-2716.

Wilson, D. J., R. N. Gonzalez, and H. H. Das. 1997. Bovine mastitis pathogens in New York and Pennsylvania: Prevalence and effects on somatic cell count and milk production. J. Dairy Sci. 80:2592-2598.

Zansky, S., B. Wallace, D. Schoonmaker-Bopp, P. Smith, F. Ramsey, J. Painter, A. Gupta, P. Kalluri, and S. Noviello. 2002. From the Centers for Disease Control and Prevention. Outbreak of multidrug resistant Salmonella Newport-United States, JanuaryApril 2002. JAMA 288:951-953.

Zhao, T., M. P. Doyle, J. Shere, and L. Garber. 1995. Prevalence of enterohemorrhagic Escherichia coli O157:H7 in a survey of dairy herds. Appl. Environ. Microbiol. 61:1290-1293. 